\title{
Advances in Environmental Biology
}

\section{Assessment of the Level of Bacterial Contamination of Some Public Swimming Pools in Jeddah City}

\author{
${ }^{1}$ Samah O. Noor, ${ }^{1}$ Azhar A. Najjar, ${ }^{1}$ Sharifah M. Alshehri, ${ }^{1}$ Nidal M. Zabermawi, ${ }^{1,2}$ Mohamed Morsi M. \\ Ahmed \\ ${ }^{1}$ Department of Biological Sciences, Faculty of Science, King Abdulaziz University, Jeddah, Saudi Arabia \\ ${ }^{2}$ Nucleic Acids Research Dept., Genetic Engineering, and Biotechnology Research Institute (GEBRI), City for Scientific Research and Technological \\ Applications. Alexandria, Egypt.
}

Correspondence Author: Azhar Najjar, Department of Biological Sciences, Faculty of Science, King Abdulaziz University, Jeddah, Saudi Arabia Email: anajjar@kau.edu.sa

Received date: 12 December 2019, Accepted date: 28 January 2020, Online date: 31 January 2020

Copyright: (C) 2020 Samah 0. Noor et al. This is an open-access article distributed under the terms of the Creative Commons Attribution License, which permits unrestricted use, distribution, and reproduction in any medium, provided the original author and source are credited.

\begin{abstract}
As the general public, the swimming pool is an essential place of entertainment. Square pools calculate extremely attractive places to spend time, especially for humans during the summer season. However, these pools can be a significant public hazard for swimmers, especially when plant life rates exceed those recommended by the United Nations agency. This research aims to determine the number of microorganisms. One hundred and sixty-five isolates were subjected to an organic chemistry analysis to identify the most widely distributed microorganisms were staphylococcus of the epidermis with twenty-seven, $3 \%$, Cereus bacilli with twenty-six, $7 \%$, enteric bacteria twelve, $1 \%$, new bacterial species, $1 \%$, Enterobacter cloacae new, $1 \%$, enteric bacteria respiratory disease seven, 3\%, half a dozen E. coli, $1 \%$ and enteric a pair of $4 \%$. Significantly, the range of microorganisms isolated throughout the winter has been reduced compared to the summer. The Bacilli Cereus with ninety-nine similarity, enteric bacteria with percentages of similarity ninety-nine nothing, enteric bacteria pneumonia with percentages of similarity ninety-nine, Enterobacter with percentages of ninety-nine similarity, enteric bacteria with ninety-nine similarity percentages, Enterobacter cloacae with ninety-nine similarity percentages and enteric bacteria with ninety-nine similarity percentages nineteen.
\end{abstract}

Keywords: Bacterial, contamination, public, swimming, pools.

\section{INTRODUCTION}

A swimming pool is a structure filled with water that is generally disinfected by different antiseptic (ozone, chlorine, or bromine). Swimming is one of the favorite activities for people, it is a healthy, active and fun way to spend leisure time particularly in summer where the temperature almost exceeds $40^{\circ} \mathrm{C}$ in Jeddah city. Thus, swimming is the best way to overcome the summer heat and relax. Furthermore, swimming pools considered a great place to practice recreational sports. However, there is increasing concern over swimming pools which considered channels for transmitting hazard infections by some fastgrowing environmental bacteria [1].

Questions have been raised about the safety of using public swimming pools. Numerous studies have reported microbial contamination of pools related to feces either by swimmers or by animals such as rodents and birds in outdoor pools [2, 3]. Moreover, pools could be polluted by feces through accidental fecal release or by washing feces in swimmers' bodies [4]. Rabi $e t$ al. [1] reported that diarrhea is the most common disease transmitted by swimming pools; an individual with diarrhea could contaminate the pools by feces easily, hence, the swimmers may swallow contaminated water especially children. In their review of infectious diseases in public swimming pools, Barna and Kádár [5] mentioned that opportunistic bacteria from fecal matter cause

infection; Symptoms range from the normal abdominal pain to the severe case of diarrhea, fever, tenesmus, and cramps. Along with a study conducted in Amman, the capital of Jordan; Rabi et al. [1] showed that 43.5\% of investigated swimming pools water were positive for fecal coliforms; which indicated to fecal contamination.

Furthermore, swimming pools could contaminate by non-fecal waste left by swimming users such as mucus, vomit, skin, and saliva; they are considered possible sources of infectious organisms. Hundreds of millions of bacteria are washed in swimming 
pools from the skin only [6]. These bacteria will be accumulated in pools water leading to pose infection to the user; if they left without treatment [1]. Several studies have revealed that most non-faecally derived bacteria isolated from pools were Pseudomonas aeruginosa and Staphylococcus, which could lead to otitis and dermatitis [7, 8, 9].

The studies showed that different outbreaks linked to pools would have been inhibited or limited by good managing for both physiochemical parameters and disinfection procedures $[4,10]$. Temperature, $\mathrm{pH}$ and free chlorine are the most factors that control the quantity and quality contamination [10]. The higher temperature in swimming pools provides excellent conditions for growing disease-causing microbes; thus, the standard temperature ranges from 27 to $29{ }^{\circ} \mathrm{C}[11]$. In swimming pools water the optimal $\mathrm{pH}$ level ranges from 7.2 to 8 , while chlorine should be 1 to $2 \mathrm{mg} / 1[10$ ]. Whenever the level of free chlorine lower than $0.4 \mathrm{mg} / \mathrm{l}$ the microbial contamination of swimming pools will increase [11]. Furthermore, chlorine loss, sore eyes, and skin spots are problems as a result of the low level of $\mathrm{pH}$ [10].

With regarding the disinfection of swimming pools, it is must define hygiene standards to reduce infections are one of the important ways to ensure the safety of both swimmers' health and swimming pools water. Hence, frequent testing of hygienic factors of swimming pools water seems essential [10]. In addition to that, to keep infection hazard under control must estimate the quality of swimming pool water frequently, test performance for disinfection systems, treatment, mentoring physical and chemicals changes of swimming pool, as well as assessment swimmers' behaviors that can change the quality of water. Many factors also affect water quality such as environmental conditions, water temperature, numbers of swimmers, time of swimming [1]. Therefore, monitoring of chemical and physical factors, particularly $\mathrm{pH}$, chlorine and temperature as well as apply the mentioned tips contribute to keeping swimming pools free from diseases causing microbes thus, swimming pools would become a healthy place for family recreation $[1,11]$. This study aims to assess the number of microorganisms contaminated by certain public swimming pools in the city center.

\section{MATERIALS AND METHODS}

\section{Measurement of physicochemical parameters}

With pH and CL test kits (Yuen Hoi pool products, China) for each pool, pH and chlorine levels were measured. This kit was supplied with a standard manufacturer chart for concentrations of $\mathrm{pH}$ and chlorine. A wireless thermometer (Hanna $\mathrm{CAL}$ CheckTM, Mauritius) checked the temperature, too.

\section{Collection of samples}

Seventeen public swimming pools in Jeddah city were investigated during two seasons. The pools were tested during summer (between 14 July to 27 September 2016) and during winter (between 25 December 2016 to 18 February 2017). Water samples were collected from surface and $30 \mathrm{~cm}$ depth for each pool in two (100) $\mathrm{ml}$ sterilized bottles. All samples delivered to the laboratory in an icebox within 4 hours maximum and processed immediately.

\section{Culturing bacteria}

All water samples in sterilized distilled water were diluted 10-1 to 10-7 using a serial dilution process. Then, $100 \mu 1$ of each dilution was distributed over the three isolation media (NA, MAC, and BA) in triplicate, then incubated at $37^{\circ} \mathrm{C}$ for 24 and 48 hours. The number of bacterial colonies for each sample of swimming pool water was counted in triplicate on the medium NA, MAC and BA after 24 to 48 hours.

\section{Isolation of bacteria:}

In order to prepare the pure culture of each bacteria on the mixed plates, the individual colonies were selected according to their morphological differences such as color, size, and shape, then isolated by inoculation Nutrient Agar (NA) and incubated at $37^{\circ}$ $\mathrm{C}$ for 24 hours. Until characterization, each pure culture was then sown on sterilized NA tilt and stored at $4^{\circ} \mathrm{C}$.

\section{Bacterial identification:}

The gram reaction of the bacterial isolates was the first step in the identification procedure. The second step for bacterial identification is a biochemical analysis which is included: Indole Methyl red Voges-procedure Citrate (IMViC), Catalase test, Oxidase test, and Urease test.

\section{Biofilm formation test:}

Biofilm formation was performed as described by Abdulamir et al., (2015). Tissue culture plates (TC microwell 96 FSI W/LID Nunclond D, Denmark) were used for testing biofilm production. The bacterial isolates were grown from a glycerol stock overnight in $10 \mathrm{ml}$ Nutrient broth (NB) at $37^{\circ} \mathrm{C}$, shaking at 150 rotations per minute (RPM). The overnight cultures were diluted at 10-3 in NB, then, inoculated into six individual wells of a microtiter plate $(150 \mu \mathrm{l}$ per well). Each separate plate contained bacterial isolates and negative control (NB without inoculation). The microtiter plates were incubated at $37^{\circ} \mathrm{C}$ for 48 hours. After that, $10 \mu \mathrm{l}$ of crystal violet was added to wells for staining then the plate incubated for 15 min at room temperature and washed gently by distilled water to eliminate any excess cells not adhere to walls of the well. To resuspend the adhered cells and dissolve the crystal violet, $70 \%$ of ethanol $(180 \mu \mathrm{l})$ was added to the plate and incubated at room temperature for 24 hours. The plate reader (The VMax, Kinetic microplate reader, Malaysia) was used for reading the microtiter plates values at $570 \mathrm{~nm}$ absorbance to determine the number of adhered cells. 


\section{Isolation of genomic DNA from bacteria:}

DNA from all bacterial isolates was extracted following the manufacturer's instructions for the Gene JET genomic DNA extraction kit (Thermo Scientific, USA). PCR was performed in region 165 using a thermal cycler (Esco healthcare, Swift max pro, Malaysia) for ribosomal DNA (rDNA) by direct primer 27F5 '(AGA GTT TGA TCM TGG CTC AG) 3 and the reverse primer 1492R 5 "(TAC GGY TAC CTT GTT ACG ACT T) 3" [12, 13]. The reaction mixture $(50 \mu \mathrm{l})$ contained $3 \mu 1$ of model DNA, $5 \mu$ of each of the primers, $25 \mu$ of green polymerase chain reaction (PCR) mixture (Promega, Go Taq ${ }^{\circledR}$ Green Master Mix, USA) and $50 \mu \mathrm{l}$ of nuclease-free gas. The PCR system was as follows: an initial cycle of $96^{\circ} \mathrm{C}$ for 1 min and 35 repeated cycles of 94 for $1 \mathrm{~min}, 56^{\circ} \mathrm{C}$ for $45 \mathrm{~s}, 72^{\circ} \mathrm{C}$ for $1 \mathrm{~min}$ and a final cycle of $72^{\circ} \mathrm{C}$ for 6 minutes. PCR products were sent to (Macrogen, Seoul South Korea) for sequencing.

\section{DNA visualization}

An electrophoretic gel (horizontal Gel Electrophoresis, Cleaver Scientific, United Kingdom) was tested on a $1.5 \%$ agarose gel for 45 mines. The gel was then colored and visualized under UV light (imager gel doc, Bio-Rad, USA) using ethidium bromide. PCR products were quantified and classified using the DNA marker (1500 bp DNA scale, Invitrogen, USA).

\section{DNA sequencing}

The cycle sequence PCR fragments were isolated using a large dye terminator X (Applied Biosystem) using cycle sequencing purification. The mixture of $45 \mu \mathrm{l}$ of SAM solution and $10 \mu \mathrm{l}$ of large dye x-terminator was well mixed and applied to the PCR tubes. The mixture was placed in a sequencer plate, then the plate was sealed and 45 minutes of the vortex at $3500 \mathrm{rpm}$. The mixture was then centrifuged at 14,000 rpm for 2 minutes. Then $20 \mu 1$ of the top layer was transferred to 96 -well plates in optical form. The plate was loaded into 96-well standards and applied to 3500 genetic analyzers. The sequences obtained from partial nucleotides of the 16S rRNA genes were aligned using codon code alignment software [14]. Phylogenetic analysis of the resulting DNA sequences and comparison with the homologous sequences of the type strains available in the Gene Bank database. The purification and sequencing steps were carried out by (Macrogen Company, South Korea).

\section{Antimicrobial susceptibility test}

Vulnerability to eight antimicrobials was obtained using the Kirby-Bauer agar disc dissemination strategy over Mueller-Hinton agar. The antimicrobials used for the exhibition were tested, tigecycline $(15 \mu \mathrm{g} / \mathrm{ml})$, metronidazole $(50 \mu \mathrm{g} / \mathrm{ml})$, corrosive fusidic $(10 \mu \mathrm{g} / \mathrm{ml})$, levofloxacin $(5 \mu \mathrm{g} / \mathrm{ml}), 1$ ampicillin-sulbactam $(20 \mu \mathrm{g} / \mathrm{ml})$, streptomycin $(10 \mu \mathrm{g} / \mathrm{ml})$, vancomycin $(30 \mu \mathrm{g}$ / $\mathrm{ml})$, oxacillin $(5 \mu \mathrm{g} / \mathrm{ml})$, BD BBL TM Sensi-Disc $(10 \mu \mathrm{g} / \mathrm{ml})$. To begin with, a single non-adulterated colony of each was removed and exchanged in the supplement broth to prepare the bacterial suspension. The suspension was balanced to coordinate the turbidity recommendations of $0.5 \mathrm{McFarland}$ using a spectrophotometer instrument. At this point, $100 \mu \mathrm{l}$ aliquots of each suspension were plated on Mueller Hinton agar plates. After that, antimicrobial circles were connected to the plates using sterile forceps and the plates hatched at $37^{\circ} \mathrm{C}$ for 24 hours. After incubation, Finally, the distances from the antimicrobial barrier area through (IZD) were measured in $\mathrm{mm}$.

\section{RESULTS}

The seasonal physiochemical parameters of the water measured in summer and winter are presented in Table 1 . The results indicated that there was a significant difference between the water temperature in summer and in winter, as expected during the summer season, which was colder. However, in terms of $\mathrm{pH}$ and chlorine, this was not the case.

Table 1: Seasonal measurements of physicochemical parameters of tested swimming pools waters

\begin{tabular}{|c|c|c|}
\hline Factors & Summer & Winter \\
\hline Temperature $\left({ }^{\circ} \mathrm{C}\right)$ & $35.31{ }^{*} \pm 0.14$ & $24.21^{*} \pm 0.13$ \\
\hline $\mathrm{pH}$ & $5.92 \pm 0.15$ & $6.04 \pm 0.15$ \\
\hline Chlorine $(\mathrm{mg} / \mathrm{L})$ & $0.57 \pm 0.03$ & $0.58 \pm 0.02$ \\
\hline
\end{tabular}

Mean \pm Stander error, *Significant difference at (p 0.05)

In the current study, there is no significant difference between the total number of bacteria isolated from the surface and at $30 \mathrm{~cm}$ depth of swimming pools during summer and winter as shown in table 2 and table 3.

Table 2: Average number of bacteria isolated in summer

\begin{tabular}{|c|c|c|}
\hline The average number of bacteria & Surface & At 30 cm depth \\
\hline Nutrient agar (NA) & $5.9 \times 10^{-5}$ & $6.1 \times 10^{-5}$ \\
\hline MacConkey agar (MAC) & $4.1 \times 10^{-5}$ & $5.3 \times 10^{-5}$ \\
\hline Blood agar (BA) & $3.7 \times 10^{-5}$ & $4.2 \times 10^{-5}$ \\
\hline
\end{tabular}

Table 3: Average number of bacteria isolated in winter:

\begin{tabular}{|l|l|l|}
\hline The average number of bacteria & Surface & At 30 cm depth \\
\hline
\end{tabular}




\begin{tabular}{|c|l|l|}
\hline Nutrient agar (NA) & $5.1 \times 10^{-5}$ & $5.7 \times 10^{-5}$ \\
\hline MacConkey agar (MAC) & $3.7 \times 10^{-5}$ & $4.1 \times 10^{-5}$ \\
\hline blood agar (BA) & $3.3 \times 10^{-5}$ & $3.7 \times 10^{-5}$ \\
\hline
\end{tabular}

In this study, the isolated bacteria from 17 swimming pools during summer and winter were investigated to the biofilm formation test. Findings reported that out of 252 bacterial isolates that recovered from the surface and at $30 \mathrm{~cm}$ depth of swimming pools in both summer and winter, there were 165 of them developed different ranges of biofilm expressed as high, moderate and low. During summer, the number of bacterial isolates in this study that recovered from the surface of swimming pools was 46 bacterial isolates produced biofilms ranges from high to low. While the number of bacterial isolates at $30 \mathrm{~cm}$ depth was 52 produced biofilms levels from high to low. During winter, the number of bacteria in this study that isolated from the surface of swimming pools was 32 bacterial isolates produced biofilms ranges from high to low. While the number of bacterial isolates from $30 \mathrm{~cm}$ depth was 35 produced biofilm levels from high to low.

Regarding the Gram staining reactions, the 165 bacterial isolates from the surface and at $30 \mathrm{~cm}$ depth during summer and winter showed different reactions to Gram stain as well as different cell morphology where 76 isolates showed Gram-negative bacilli with 46.1\%, 45 isolates indicate Gram-positive cocci with 27.8\%, 44 isolates showed Gram-positive bacilli with $26.7 \%$. In the current study, the 165 isolates were subjected to biochemical analysis for identification. According to biochemical analysis, the most distributed bacteria were Staphylococcus epidermidis with $27.3 \%$, Bacillus cereus with $26.7 \%$, Klebsiella oxytoca $12.1 \%$, Serratia marcescens 9.1\%, Enterobacter cloacae 9.1\%, klebsiella pneumonia $7.3 \%$, Escherichia coli $6.1 \%$ and Salmonella enterica $2.4 \%$. Noticeably, the isolated bacteria number during winter was decreased compared to summer. Also, findings indicated the absence of Escherichia coli and Salmonella enterica during winter. After that, eight overwhelming pool recurrences were chosen to aid atomic research and proof of distinction using $16 \mathrm{~S}$ rDNA DNA sequencing. Advanced atomic strategies have been used to organize the distinction of species related to bacteria for the various separate microbes. The PCR profiles of the intensified 27F 5 / 1492R combine harvesters from various confines appeared strongly sharp groups using agarose gel as shown in Figure 1. The DNA groups analyzed using instruments of the quality bank nucleotide impact arrangement and appeared that the separate ones were distinguished as Staphylococcus epidermidis with $99 \%$ similarity rate, Bacillus cereus with $99 \%$ similarity, Klebsiella oxytoca with $99 \%$ similarity rate, Klebsiella pneumoniae with $99 \%$ similarity rate, Enterobacter asburiae with $99 \%$ proximity rate, Escherichia fergusonii with $99 \%$ similarity rate, Enterobacter cloacae with $99 \%$ similarity rate and Salmonella enterica with $99 \%$ similarity rate.

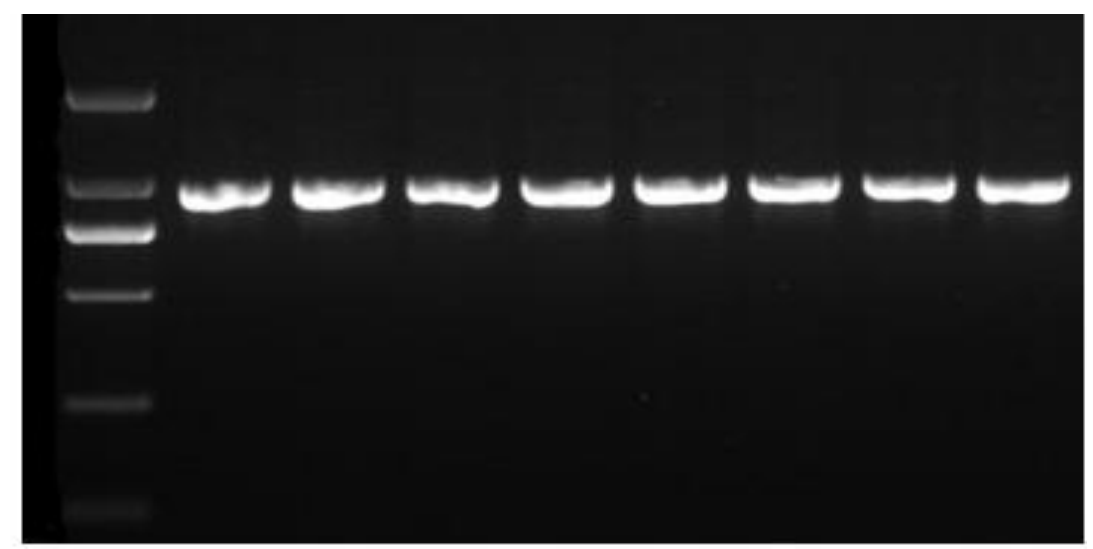

Fig. 1: The 1500 bp 16S rDNA amplicon agarose gel electrophoresis after the purification compared with DNA Ladder 1kb on a $1 \%$ agarose gel. Lane 1: $1 \mathrm{~kb}$ DNA leader and Lane 2-9: indicate eight of bacterial isolates.

In the current study, the genetically identified bacterial strains from the surface and at $30 \mathrm{~cm}$ of 17 swimming pools in both summer and winter were subjected to antibiotic-resistant tests using 8 different antibiotics. Most of the bacterial strains showed sensitivity for most of 8 different antibiotics.

The findings reported that all bacterial isolates showed relative levels of antibiotic resistance against 3 antibiotics which are Kanamycin (KS), Ceftriaxone (CRO) and Colistin sulfate (CT). The bacterial isolates indicate different antibiotics sensitivity to 5 antibiotics, including Fusidic acid (FA); Streptomycin (S); Vancomycin (VA); Levofloxacin (LEV) and Tigecycline (TGC).

\section{DISCUSSION}

The pools are exceptionally attractive places for entertainment, especially during the summer season for people. In any case, these pools can be a major open wellness hazard for swimmers, especially when contagious levels exceed those prescribed by WHO [10]. Our study explored the impact of regular varieties of parasite levels in the waters of swimming pools in Jeddah, taking into account the physicochemical characteristics of these pools. The result of the current reflection revealed that the physicochemical parameters did not comply with the suggested guidelines [15]. In the current research, the total number of bacteria does not show a significant difference among surface and at $30 \mathrm{~cm}$ depth of swimming pools. This is consistent with the study conducted by Saberianpour et al. [10] reported that bacterial contamination does not different along with the high and low 
depth of 21 swimming pools. The results of the current study showed that 165 bacterial isolates formed various ranges of biofilm during both summer and winter; were 46 isolates of them detected from surface of swimming pools during summer, 52 isolates recovered at $30 \mathrm{~cm}$ depth of swimming pools during summer, 32 were isolated from surface of swimming pools during winter and 35 isolates recovered at $30 \mathrm{~cm}$ depth of swimming pools during winter. Abdulamir et al., [16] reported that biofilm divided into 3 types; high, moderate and low. Barna and Kádár [5] demonstrated that the production of bacterial biofilm in swimming pools yielded to grow a large number of bacteria due to the consequences of disinfection deficiency. According to Al-Zuhairi [17], biofilm indicates public health risk and it is hard to eliminate from surfaces. In the case of Gram stain, this study has shown that the bacterial isolates revealed three reactions; Gram-negative bacilli, Gram-positive cocci, Gram-positive Coco bacilli [ 18 ], stated that the identification of bacteria by Gram stain is a convenient method to describe the morphological characteristics of microscopic appearance and pattern of stain either positive or negative. the results showed there was an agreement between the biochemical and 16s rDNA sequence analyses on the genus and species levels in some bacterial isolates include Salmonella enterica, Bacillus cereus, Staphylococcus epidermidis, Klebsiella oxytoca, and klebsiella pneumonia. While in some bacterial isolates, there was a match in genus and mismatch in species including Escherichia fergusonii where it was biochemically identified as Escherichia coli also, Enterobacter asburiae where it was biochemically identified as Enterobacter cloacae. However, there was a disagreement on both genus and species levels in the other isolate included Enterobacter cloacae where it was biochemically identified as Serratia marcescens. A study was done by Hemraj et al., [19], stated that there are many biochemical tests could be utilized to differentiate the bacteria such as sulfate reduction test, IMViC, urease test, catalase production test, oxidase test and casein hydrolysis. According to [20] who reported that phenotype-based tests including Gram stain and biochemical tests are generally not accurate as identification based on genotypic methods. The mentioned study also stated that $16 \mathrm{~S}$ rRNA gene sequence analysis can better identify to poorly described, rarely isolated, or phenotypically aberrant strains and could lead to the recognition of novel pathogens and non-cultured bacteria [20]. Generally, the current study found that the highest isolated bacteria from swimming pools were as follows: S. epidermidis with $28.6 \%$, B.cereus with $27.1 \%, \mathrm{~K}$. oxytoca with $13.1 \%$, E. asburiae with $9.2 \%$, E. cloacae with $9.1 \%$, k. pneumonia with $7.2 \%$, E. fergusonii with $5.1 \%$ and $S$. enterica with $2.1 \%$. As clearly discussed above, S. epidermidis was the most isolated bacteria from swimming pools in our study. In this research, B. cereus was the second-highest level of contamination in swimming pools [21]. The studies by Itah and Ekpombok [9] and [22] revealed the most isolated bacterium from swimming pools was B. cereus. They suggested that the reason for the spread of this type of bacteria was resistant to disinfectants because it forms spores. In this research, $B$. cereus was the second-highest level of contamination in swimming pools. The studies by Itah and Ekpombok [9] and [22] revealed the most isolated bacterium from swimming pools was B. cereus. They suggested that the reason for the spread of this type of bacteria was resistant to disinfectants because it forms spores. In a similar study, done by Bello et al., [23] stated that B. cereus could lead to gastroenteritis by the swallowed water of swimming pools. The finding of the current study recorded isolation of many types of Enterobacteriaceae including E. asburiae, E. cloacae, E. fergusonii, K. oxytoca, K. pneumoniae and S. enterica respectively. Osei-Adjei et al did a study., [24] reported that the existence of Enterobacteriaceae bacteria in the water of swimming pools is an indication of fecal contamination and displayed that the disinfection system of pools was not efficient to eliminate contamination [25]. Regarding the antibiotic in the current study, the bacterial isolates were investigated toward 8 antibiotics including Kanamycin (KS), Ceftriaxone (CRO), Colistin sulfate (CT), Fusidic acid (FA), Streptomycin (ST), Vancomycin (VA), Levofloxacin (LEV) and Tigecycline (TGC). By considering the findings of the current study, the swimming pools of Jeddah were recorded relatively high averages of bacterial contamination during summer; this is probably due to high temperatures and low concentration of chlorine which is inefficient to eliminate bacteria in swimming pools. Thus, this study suggests that the chlorine level of public swimming pools should be retested or changed by stronger products.

\section{The conflict of paper}

The authors declare that they have no conflicts of interest.

\section{ACKNOWLEDGMENT}

The authors acknowledge assistance from the Dept. of Biological Sciences, Faculty of Science, King Abdulaziz University (KAU), Jeddah, KSA.

\section{REFERENCES}

[1] Rabi, A., Khader, Y., Alkafajei, A., and Aqoulah, A. A. (2007). Sanitary conditions of public swimming pools in Amman, Jordan. International Journal of Environmental Research and Public Health, 4(4), 301-306.

[2] WHO (World Health Organization), 2006. Guidelines for Safe Recreational Water Environments. Swimming Pools and Similar Environments. Geneva, Switzerland: WHO Press. pp: 100-105. Make references like this style.

[3] Nichols, G., 2006. Infection risks from water in natural and man-made environments. Euro Surveill, 11 (4), 76-78.

[4] Papadopoulou, C., Economou, V., Sakkas, H., Gousia, P., Giannakopoulos, X., Dontorou, C., and Leveidiotou, S. (2008). Microbiological quality of indoor and outdoor swimming pools in Greece: an investigation of the antibiotic resistance of the bacterial isolates. International Journal of Hygiene and Environmental Health, 211(34), 385-397.

[5] Barna, Z., and Kádár, M. (2012). The risk of contracting infectious diseases in public swimming pools: a review. Annali dell'Istituto Superiore di Sanita, 48(4), 374-386. 
[6] Tate, D., Mawer, S., and Newton, A. (2003). The outbreak of Pseudomonas aeruginosa folliculitis associated with a swimming pool inflatable. Epidemiology and Infection, 130(2), 187-192.

[7] Klapes, N. A., and Vesley, D. (1986). Rapid assay for in situ identification of coagulase-positive staphylococci recovered by membrane filtration from swimming pool water. Applied and Environmental Microbiology, 52(3), 589-590.

[8] Alcock, S. R. (1977). Acute otitis externa in divers working in the North Sea: a microbiological survey of seven saturation dives. Epidemiology and Infection, 78(3), 395-409.

[9] Itah, A. Y., and Ekpombok, M. U. M. (2004). Pollution status of swimming pools in south-south zone of south-eastern Nigeria using microbiological and physicochemical indices. West African Journal of Biological and Applied Chemistry, $41,1-10$.

[10] Saberianpour, S., Momtaz, H., Ghanbari, F., and Mahmodi, F. (2015). Assessment of bacterial and fungal contamination in public swimming pools in Shahrekord-Iran. Journal of Tropical Diseases and Public Health, 4(2), 190-194.

[11] Rasti, S., Assadi, M. A., Iranshahi, L., Saffari, M., Gilasi, H. R., and Pourbabaee, M. (2012). Assessment of microbial contamination and physicochemical condition of public swimming pools in Kashan, Iran. Jundishapur Journal of Microbiology, 5(3), 450-456.

[12] Lane, D. J. (1991). 16S/23S rRNA sequencing. Nucleic acid techniques in bacterial systematics, 115-175.

[13] Weiss, L. M., and Vossbrinck, C. R. (1999). Molecular biology, molecular phylogeny, and molecular diagnostic approaches to the microsporidia. In the microsporidia and microsporidiosis (pp. 129-171). American Society of Microbiology.

[14] Barth, P. G., Majoie, C. B., Caan, M. W., Weterman, M. A., Kyllerman, M., Smit, L. M., and Poll-The, B. T. (2007). Pontine tegmental cap dysplasia: a novel brain malformation with a defect in axonal guidance. Brain, 130(9), 22582266.

[15] Naghipour D., Ashrafi S.D. and Taghavi K. (2018), Data of heavy metals in soil and groundwater at Kiwi gardens of Amlash in Guilan Province, Iran, Data Brief, 18, 1556-1561.

[16] Abdulamir, A. S., Jassim, S. A., Hafidh, R. R., and Bakar, F. A. (2015). The potential of bacteriophage cocktail in eliminating Methicillin-resistant Staphylococcus aureus biofilms in terms of different extracellular matrices expressed by PIA, ciaA-D and FnBPA genes. Annals of Clinical Microbiology and Antimicrobials, 14(1), 49.

[17] Al-Zuhairi, H. A. (2018). Production of Slime Layer by Staphylococcus Epidermidis Isolated from Hip and Knee Joint Infections during Revision Arthroplasty of Patients in Abn-Sina Hospital in Baghdad. Journal of Global Pharma Technology.

[18] Coico, R. (2001). Gram staining. Current Protocols in Immunology, 23(1), 30.

[19] Janda, J. M., and Abbott, S. L. (2007). 16S rRNA gene sequencing for bacterial identification in the diagnostic laboratory: pluses, perils, and pitfalls. Journal of Clinical Microbiology, 45(9), 2761-2764.

[20] Hemraj, V, Diksha, S. and Avneet, G. 2013. A Review on Commonly used Biochemical Test for Bacteria Innovare Journal of Life Science, 1 (1), 1-7.

[21] Janda, J. M, and Abbott, S. L. 2007. 16S rRNA gene sequencing for bacterial identification in the diagnostic laboratory: pluses, perils, and pitfalls. J Clin Microbiol. 2007;45(9):2761-4.

[22] Amala, S. E., and Aleru, C. P. (2016). Bacteriological quality of swimming pools water in Port Harcourt metropolis. Natural Science, 8(03), 79 .

[23] Shittu, O. B., Olaitan, J. O., and Amusa, T. S. (2008). Physico-chemical and bacteriological analyses of water used for drinking and swimming purposes in Abeokuta, Nigeria. African Journal of Biomedical Research, 11(3).

[24] Bello, O. O., Mabekoje, O. O., Egberongbe, H. O., and Bello, T. K. (2012). Microbial qualities of swimming pools in Lagos, Nigeria. International Journal of Applied, 2(8), 89-96.

[25] Osei-Adjei, G., Sarpong, S. K., Laryea, E., and Tagoe, E. (2014). Bacteriological quality assessment of swimming pools in the Osu-Labadi Area, Accra. Journal of Natural Sciences Research, 4(19), 126-129.

[26] World Health Organization. (2006). Guidelines for safe recreational water environments: swimming pools and similar environments. In Guidelines for safe recreational water environments: swimming pools and similar environments. Geneva, pp. 26-59. 